\title{
ANYAMAN PITA KULIT PADA GERABAH, MENGHASILKAN PRODUK BARU
}

\author{
Oleh : Koentoro Soebijarso
}

\section{RINGKASAN}

Kulit jadi (leather), selanjutnya dalam tulisan ini disebut kulit, digunakan untuk pembuatan barang-barang sebagai berikut : pembuatan berbagai jenis dan model alas kaki (foot wear), garment dan sarung tangan kulit; barang-barang dari kulit seperti tas, koper, dompet, ikat pinggang ; alat-alat olah raga ; jok mebel ; sol ; kulit teknis, dan lain-lain.

Kulit untuk menganyam sampai saat ditulis ini tidak terdapat di umum atau diperjualbelikan, atau tidak dikenal. Ide ini dilontarkan untuk menghasilkan produk yang sama sekali baru yaini produk gerabah yang dianyam dengan pita-pita yang terbuat dari kulit. Supaya produk baru ini dikenal di masyarakat maka diadakan pameran. Transfer teknologi diajarkan dalam pelatihan-pelatihan.

Proses penganyaman dilakukan terhadap gerabah yang berbentuk vas atau berleher, dan yang telah diproduksi secara melembaga oleh industri kecil di sentra-sentra gerabah. Kulit yang dipergunakan adalah lembaran kulit (side) dan dibuat pita-pita dengan pertolongan mesin potong pita. Motif-motif anyaman dikembangkan oleh para peneliti yang ada di Balai Besar Penelitian dan Pengembangan Industri Barang Kulit, Karet dan Plastik (BBKKP). Hasil adalah produk baru yang berupa gerabah yang telah dianyam dengan pita-pita kulit.

\section{Tujuan}

Pencetusan ide tentang anyaman pita kulit pada gerabah didorong oleh suatu tekat untuk memberikan wajah baru atau kenampakan baru dari produk gerabah yang dibuat oleh para perajin di Yogyakarta. Sebagaimana kebiasaan para perajin 
bah di Yogyakarta, mereka membuat gerabah dengan bahan baku tanah liat yang dapat di D I Yogyakarta. Tanah diolah dan dibentuk dengan cara tradisional enjadi pelbagai jenis produk dengan aneka ragam bentuk, dan setelah melalui oses pembakaran, diperoleh barang-barang gerabah warna tunggal kecoklatan. rabah tradisional ini kemudian dipasarkan. Diperkirakan dengan memberikan jah baru yaini menganyam dengan pita-pita kulit akan didapat suatu corak baru ingga diperkirakan akan mempunyai nilai tambah lebih, serta dapat menambah nghasilan para perajin dan memperluas jaringan pemasarannya.

\section{Sistematika Penjabaran Ide}

Setelah ide dasar dan tujuan diletakkan, maka perlu perujudannya. Hal ini akukan dengan membuat organisasi dan sekaligus menggambarkan sequence aksanaannya sebagai berikut :

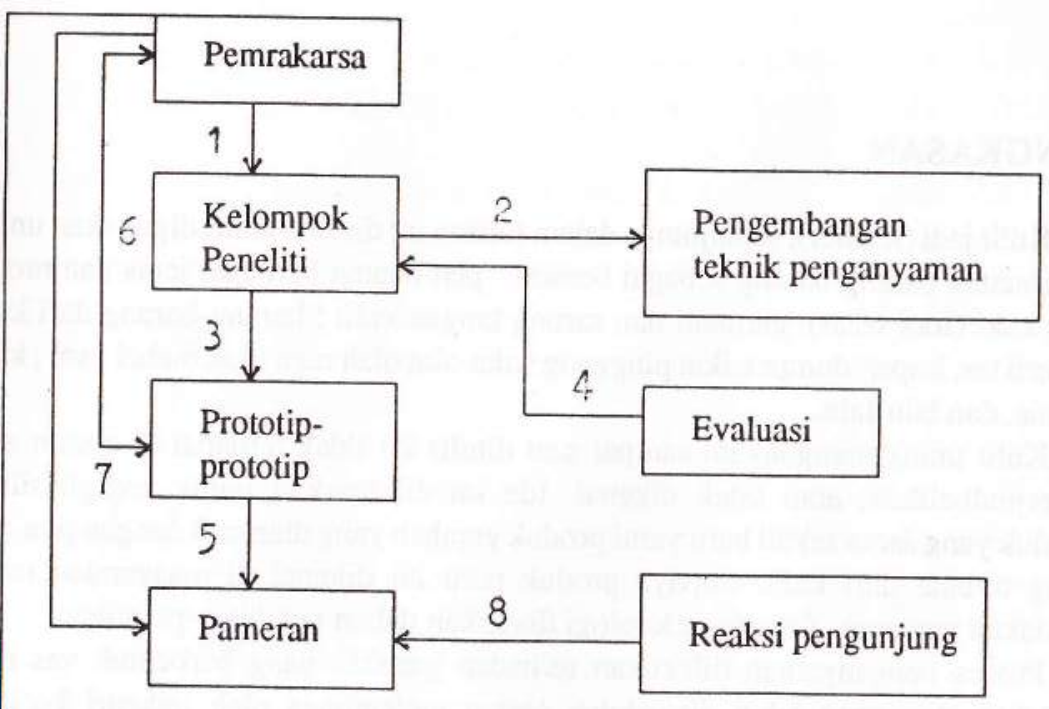

Pelatihan

nbar 1.

Skema Organisasi dan Sequence Penjabaran Ide.
Adapun urutan dari penjabaran ide sehingga terujud suatu bentuk baru dari barang yang sebelumnya tidak dikenal, diuraikan seperti di bawah ini :

Sequence 1 (transfer ide kelompok)

Oleh pemrakarsa, ide diberikan kepada Kelompok Penelitian Barang Kulit yang ada di BBKKP. Kelompok ini diperkuat oleh para ahli dengan susunan disiplin terdiri dari :

\section{- Seorang ketua}

- Seorang disainer barang kulit

- Lima orang ahli perakitan barang kulit yang telah purna diklat dari seorang tenaga ahli PBB di bidang pembuatan tas, dompet dan barang kulit kecil lainnya.

- Beberapa pembantu peneliti

- Seorang ahli bidang peragaan dan pameran, dan dibantu staf

- Seorang ahli bidang penyamakan kulit

- Staf tata usaha.

Sequence 2 (Kelompok Peneliti pengembangan teknik anyaman)

Setelah ide dasar dikemukakan kepada semua kelompok yang akan melaksanakan penjabaran ide sehingga menjadi bentuk nyata, maka kelompok mengadakan penelitian tentang hal-hal yang berkaitan dengan pelaksanaan pembuatan produk anyaman pita kulit pada gerabah bentuk vas. Dalam pelaksanaan pembuatan gerabah bentuk vas dengan anyaman pita kulit maka pedoman yang tersebut dalam uraian C \& F effect tersebut di atas.

\section{Bahan dan Peralatan}

Bahan -bahan dan peralatan yang digunakan untuk pembuatan gerabah yang dianyam dengan pita kulit adalah :

- kulit yang telah terpotong menjadi pita

- gerabah bentuk vas, aneka ragam bentuk dan desain yang diperoleh dari perajin Kasongan dan Pujon, Kabupaten Bantul, DI Yogyakarta.

- meja kerja.

- mesin potong kulit untuk membuat pita, untuk membuat lembaran kulit samak nabati, sehingga diperoleh pita-pita kulit yang mempunyai lebar yang. sama dan berbentuk pipih, berwarna natural, atau diwarnai sebelumnya. 


\section{Metoda Penelitian Pembuatan Anyaman.}

Desainer memilih gerabah yang akan dianyam, serta menentukan desain anyaman yang akan diterapkan pada gerabah. Teknik penganyaman sepenuhnya menggunakan ketrampilan tangan yang merupakan perpaduan antara seni + teknik. Simpul-simpul anyaman diberi asesori yang terbuat dari kayu aneka bentuk dan warna.

Hasil yang diperoleh dari desain awal ini meupakan suatu pra prototipe dan diadakan evaluasi pada urutan berikutnya.

Sequence 3 (pengembangan teknik penganyaman evaluasi)

Hasil dari pra prototipe dievaluasi secara visual oleh kelompok. Evaluasi terutama pada nilai estetika dari produk, keserasian antara pita kulit yang dianyam - model anyaman - bentuk gerabah, mengenai warna kulit, warna gerabah, permukaan yang terkena anyaman dan kombinasi asesori.

Sequence 4 (hasil evaluasi $>$ kelompok peneliti)

Hasil evaluasi merupakan feedback kepada kelompok dan digunakan selanjutnya untuk trial pembuatan barang, dalam jumlah yang cukup banyak dan dikerjakan oleh seluruh kelompok.

Sequence 5 (kelompok $>$ pembuatan prototipe)

Langkah urutan selanjutnya adalah pembuatan beberapa prototipe gerabah yang dianyam dengan pita kulit. Pekerjaan ini dilakukan oleh para ahli yang bekerja di Kelompok Peneliti Barang Kulit pada Balai Penelitian dan Pengembangan Industri Barang Kulit, Karet dan Plastik. Sistem yang digunakan adalah pengembangan ketrampilan diri, dengan panduan serta petunjuk teknis secara langsung, diberikan oleh desainer yang mempunyai motifasi, yang selanjutnya masing-masing ahli mengadakan deversifikasi anyaman menurut versi masing-masing. Pekerjaan ini adalah pekerjaan seni dan ketrampilan yang merupakan penjabaran langsung dari daya imajinasi ahli masing-masing. Pattern umum yang dianut adalah anyaman dan simpul yang tidak menutupi secara menyeluruh permukaan gerabah yang dianyam. Hasil anyaman terlihat pada gambar di lampiran.

Sequence 6 (prototipe $\longrightarrow$ pameran)

Semua hasil prototipe dipamerkan dalam pameran 'Pekan Kerajinan III' di Balai Sidang Senayan tanggal 7 s/d 15 Juli 1990. Maksud dari dipamerkannya produk ini adalah untuk memperkenalkan kepada masyarakat tentang hasil penelitian yang dikerjakan oleh BBKKP, serta mencari masukan-masukan untuk perbaikan dan penyempurnaan produk baru tersebut.
Sequence 7 (Pameran)

Pemrakarsa memberikan lampu hijau untuk memamerkan semua prototipe dalam pameran.

\section{Sequence 8 (masukan dari para pengunjung pameran)}

Secara umum reaksi dari para pengunjung cukup positip, dengan adanya kontak langsung tentang segala seluk beluk produk baru ini. Reaksi datang dari BIPIK, Dirjen Industri Kecil, Yayasan Pengembangan Design, dan para pengunjung yang datang dari luar negeri. Reaksi ini merupakan feedback untuk pencetus ide guna tindak lanjut.

Sequence 9 (ide $\longrightarrow$ transfer teknologi)

Dari hasil pameran dan masukan-masukan yang diperoleh disimpulkan perlunya diadakan transfer teknologi, yang ditujukan kepada para perajin gerabah untuk memberikan pelatihan bagaimana memotivir mereka untuk membuat produk baru dari gerabah yang telah diproduksinya. Dengan pelatihan ini maka diharapkan para perajin tergugah imajinasinya, sehingga pengusaha berusaha membuat produk baru guna pengembangan pemasaran produknya dari hasil deversifikasi produk yang secara tradisional dibuatnya. Ini berarti akan menambah pendapatan perajin, atau menimbulkan peluang kerja baru bagi masyarakat.

\section{Faktor-faktor yang Mempengaruhi Pelaksanaan Pembuatan}

Dalam mengembangkan produk-produk baru di masyarakat dari hasil penelitian dan pengembangan, perlu diadakan perhatian tentang faktor-faktor yang diperkirakan akan mempengaruhi pelaksanaan pembuatan. $\mathrm{Hal}$ ini penting untuk menguji seberapa jauh pemacuan teknologi akan efektip mencapai tujuan. Faktor-faktor tersebut meliputi hal-hal yang berkaitan dengan input dan produk yang akan dikembangkan di masyarakat. Pembahasan ini hanya menyangkut aspek teknis dan ekonomis dan hambatan-hambatan yang diperkirakan akan timbul. Secara skematis maka faktor-faktor tersebut dapat digambarkan (Gambar 2) pada diagram $C \& E$. 
Kepada Kelompok Peneliti Barang Kulit dan Staf diucapkan terima kasih, karena membantu merekayasa desain, pelatihan, kepada Staf peragaan dan pameran produk anyaman pita kulit pada gerabah di Pekan Kerajinan III di Jakarta. Kepada Tata Usaha dan seluruh Staf diucapkan terima kasih pula hingga terujudnya penulisan ini.

Tegur sapa sangat dinantikan guna masukan dalam perbaikan tulisan ini.

Yogyakarta, Juni 1991
Pemrakarsa ide, penulis

Koentoro Soebijarso

\section{LAMPIRAN}

Foto dari Produk Anyaman Pita Kulit pada Gerabah

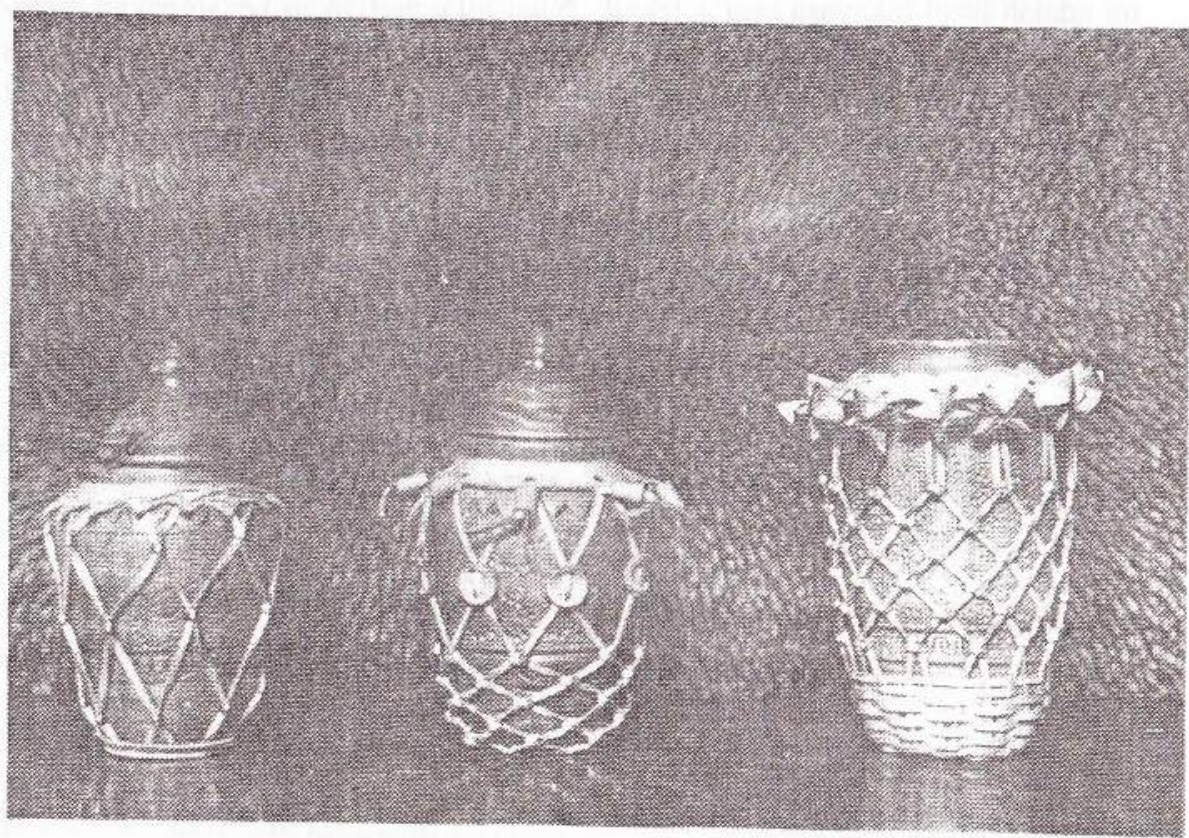

\section{DAFTAR PUSTAKA}

1. Adam E.E. Jr., Ebert R.J., Production and Operations Management, PHI editors, 2nd ed.ISBN : 0-13-72506-9-X.

2. Brauners W.K.M., System Analysis, Planning \& Decision Models, Elsiever Scientific Publishing Co., 1976, ISBN : 0-444-41438-9.

3. Departemen Perindustrian, Gerabah Halus Berglasir untuk Alat Makan Minum, SII 1918-86, Tahun 1986.

4. Departemen Perindustrian, Kulit Sapi untuk Tas/Koper, Mutu dan Cara Uji, SII 0241-79, SNI 0335-89A.

5. Departemen Perindustrian, Kulit Sol Sapi, Mutu dan Cara Uji, SII 0019-79, SNI 0235-89A.

6. Fritz S., Gerbereichemie und Gerbereitechnoloogi, 2 Auflage, A-Verlag $\mathrm{GmbH}$, Berlin, 1951.

7. Gustavson, K.H., The Chemistry of Tanning Processes, API Publishers, New York, 1956.

8. Philip E. Hicks, Introduction to Industrial Engineering \& Management Science, Mc Graw Hill, cp. 1977, ISBN : 0-07-028767-8.

9. Philip H. Francis, Principles of $R \& D$ Management, AMACOM, 1977, First printing, ISBN : 0-8144-5451-8. 